\title{
DISCUSSSION ON THE IDEA AND TECHNOLOGY IN LABOR AUGMENTING SOLOW MODEL BESIDES PHYSICAL AND HUMAN CAPITAL COMPLEMENTARITY ERDIL, Erkan* \\ KALYONCU, Kahraman
}

Abstract. It is suggested that developing countries could catch up with the developed world if only they attained increased levels of human development. The links between growth and human development are complex even with human capital its self and human capital to the physical capital. Besides large disparities in indicators of human well-being, such as life expectancy and educational attainment, not all countries with relatively higher levels of human development handles to achieve high long-term economic growth rates (United Nations, 2006). As data points out that in order to reach the convergence among the countries, not only the physical to human capital ratio plays crucial role but also the income level specific effects. What these income level specific effects indicate in our study? How they are related with technology and ideas? Technologies are the way in which inputs to the production process are transformed into output and ideas improve the technology of production. Therefore, a new idea allows a given bundle of inputs to produce more or better output and ideas are non-rivalrous. Once an idea is created, anyone with knowledge of the idea can take advantage of it. Ideas are partially excludable while technologies in the inputs are mostly excludable since goods and inputs suffer from tragedy of commons. Thus, in order to benefit efficiently from the ideas and technology, the macro economic stability, social cohesion, common structural habits or feeling secure about the life, geography, religion, corruption, quality of institutions and governance structures matter for economic growth. That is what dummies stands for and that goes with what Bulutay (1995) emphasizes about the ambiance created by the countries.

JEL Codes

Keywords: Solow Model, Technology, Labor Augmenting, Physical Capital, Human Capital, Complementarity

* Erkan Erdil, METU, department of economy, Ankara, erdil@metu.edu.tr, Kahraman Kalyoncu, METU, department of economy, Ankara, kkalyunc@yahoo.com 


\section{Introduction}

World markets are far from evenhanded and there are numerous conditions that do not favour a narrowing of the income divergence between countries. Wealthier countries have better "endowments" which give them privileged access to capital markets and make them less exposed to shifts in worldwide goods markets. International shareholders commonly favor countries with greater material goods and better-developed human capital, infrastructure and institutions, where these endowments make sure lower investment risk. However, in lessdeveloped countries, economies and export structures are less diversified, making them much more vulnerable to shifts in commodity prices and to shocks in international financial markets besides these countries having less of a voice in the negotiation processes setting the rules governing global markets.

The physical and human capital interaction as "endowments" are not substitutes but complementarities (Bulutay, 1995) while Barro and Sala-i-Martin (1995) conclude that the growth rate of output is higher if the magnitude of the gap between the ratio of physical to human capital and the steady state value of this ratio is larger. Available technological level in physical capital, $\mathrm{K}$, and improvement in it needs similar improvements in skilled labor, H, (Erk et al., 1998) and one of the main reasons for physical capital not to flow from rich to poor countries is differences in human capital and its external benefits to physical capital (Lucas, 1990). As goods and services suffer from the "tragedy of the commons" so do their degrees of excludability, physical and human capital interaction as inputs are also affected by the tragedy of commons and externalities. The human capital is considered to be the key for most of the evidence of income distribution and economic growth in the world. Briefly, Doepke (2007) predicts the convergence or divergence depending on the initial level of human stock, since the richer countries have better "endowments" such as in physical to human capital ratio which give them preferential access to capital markets and make them less vulnerable to shifts in global commodity markets. Therefore, it is not 
the absolute sizes of $\mathrm{K}$ and $\mathrm{H}$ but their relative concentration values should be the key determinant of long-term economic growth.

A recently emerging concurrence about the world wide economic consideration suggests that we should not only just merely focus on economic factors but we also should also take into account the historical and institutional setting of each country. The analysis should focus on an opinion of the significant constraints on growth such as how the boundaries in mobilizing adequate domestic or foreign finance, the levels of human capital and technological capabilities, the governance structures and the poor functioning of institutions that regulate markets or provide public goods and social services. The significance and importance of these boundaries tend to be different from country to country. In this study, we will first focus on the physical to human capital endowments of the countries and secondly we will focus on the income level dummies effects on the income dynamics. Since technologies are the way inputs to the production process are transformed into output where ideas improve the technology of production, we will consider these dummies how effective the ideas spread in the world. Therefore, a new idea allows a given bundle of inputs to produce more or better output and ideas are non-rivalrous. Once an idea is created, anyone with knowledge of the idea can take advantage of it. Ideas may be partially excludable while technologies in the inputs are mostly excludable since goods suffer from tragedy of commons.

In the next section, we discuss the reasoning why we should set physical to human capital interaction in the production function. In the third section, we evaluate what could be the reasons behind the income differences. In the fourth section, we describe the data and report the estimation result. Finally, we conclude on the findings.

\section{Physical and human capital interaction}

Bulutay (1995) points out that the essential interaction among inputs is not substitution but complementarities. Barro and Sala-i-Martin (1995) also think the imbalances between the levels of physical 
and human capital and note that the growth rate of production is higher, the larger the degree of the gap between the ratio of physical to human capital and the steady state value of this ratio. When Barro and Sala-i-Martin (1995) consider that to generate long-term growth, human capital production may be seen as an alternative to improvement in technology even though the accumulation of human capital differs from the creation of knowledge in the form of technological progress. The human capital is skills embodied in a worker and using these skills in an activity precludes their use in another activity. For that reason, human capital is a rival good and it is a subject to tragedy of commons which makes it an excludable input. Due to that physical capital and human capital should be matched with these degrees of excludability; otherwise it will be a waste and the complementary and excludability should depend on the production process.

Doepke (2007) considers the case of two countries called "A" and " $B$ " in this model where their amount of human capital, $\mathrm{H}_{\mathrm{A}}=\mathrm{H}_{\mathrm{B}}$. However, they are different only in their initial levels of capital stock but they have the same economic dynamics. In the long-run ratio of per-capita capital, $\mathrm{k}_{\mathrm{t}}$, will be constant, these two economies will be identical in terms of the level of physical and human capital and output. However, when one of the countries has the lower level of physical capital, then this country is expected to grow faster than the other. Therefore, convergence occurs. However, when a country has only half as much human capital as of other country and if the human capital will grow at the same constant rate in both countries, the ratio of human capitals between countries will be always the same. Therefore, the physical to human capital ratios will be constant and the long-run ratio of physical capital will be the same as well. As a result, divergence occurs. The human capital is the key for most of the evidence on the world income distribution and economic growth in order to reach the convergence or divergence.

The law of human capital motion requires the use of existing human capital and it is the key ingredient in the production of education to 
create knowledge. Future human capital is produced by not only the present level of human capital, but also the contribution of the physical capital and the amount of future human capital depends mostly on the fraction of time spent on education. Erk et al. (1998) consider that available technological level (covered in $\mathrm{K}$ ) and improvement in it needs parallel improvements in $\mathrm{H}$. Therefore, as they emphasize that it is not the absolute sizes of physical capital (K) and the skilled-labor $(\mathrm{H})$ but their relative concentration values should be the key determinant of long-term economic growth. To support this idea, one of the main reasons for physical capital not to flow from rich to poor countries is the differences in human capital and its external benefits to physical capital (Lucas, 1990).

We like to indicate another point: any positive very small constant (c) amount of physical capital could be enough to carry on the production process in the commonly used production function as such

$$
Y_{t}=F\left[K_{t}, H_{t}, A_{t} L_{t}\right]=F\left[c, H_{t}, A_{t} L_{t}\right]=c^{\alpha} H^{\beta}(A L)^{1-\alpha-\beta}
$$

or same is true for human capital

$$
Y_{t}=F\left[K_{t}, H_{t}, A_{t} L_{t}\right]=F\left[K_{t}, c, A_{t} L_{t}\right]=K^{\alpha} c^{\beta}(A L)^{1-\alpha-\beta} c>0
$$

where $\mathrm{Y}$ stands for GDP level, A for technological level, $\mathrm{K}$ for physical capital, $H$ for human capital and $L$ for raw labor. $\alpha$ and $\beta$ are the share paramaters and $t$ is for the time specific term.

As it can be easily seen, any type of machines requires skilled labor to operate. Therefore, our production function is as follows.

$$
\begin{aligned}
& Y_{t}=F_{t}\left[A_{t}, \frac{K_{t}}{H_{t}}, L_{t}\right]=\left(\frac{K}{H}\right)_{t}^{\alpha}\left(A_{t} L_{t}\right)^{1-\alpha} \\
& \frac{Y}{L}=A\left[\frac{K}{H^{*} Y}\right]^{\left(\frac{\alpha}{1-\alpha}\right)}=A \chi
\end{aligned}
$$

The production function is represented by two terms: accumulated term $(\chi)$ and technological term (A). The complementarities between human capital and physical capital are the nature of the production procedure. Machines require skilled workers to 
operate them and to repair them. Modern and productive process needs a literate workforce. Workers should be able to read instructions and comprehend information contained in the literature distributed by extension agents and understand the contents of a repair manual for agricultural equipment while modern services (travel, finance, tourism) have need of numeracy people who can make simple calculations quickly and accurately. Consequently, a country gives priority to physical capital and it gives priority to human capital too. There are also empirical supports for this interaction. Ramcharan (2004) concludes from the more proper econometric evidence that the important complementarities do exist. In Korea, human capital has made an extra contribution to income growth by heartening the physical capital investment and the rates of return to investment are high due to a well-educated labor force (Lee, 2007). Islam (1995) reveals that coefficients of human capital are negative as in Rogers and Dowrick (1997) findings ${ }^{1}$.

\section{Evaluation in income disparity}

Neoclassical growth model contain remarkable success and failure in its anticipation. Therefore, we have to mention some stylized facts of growth (Doepke, 2007). Most economies grow over time both in aggregate and per capita terms. Growth rates differ substantially between countries and even small differences in annual growth rates accumulate to big differences in income in the long run while in the long run, cyclical fluctuations matter much less than the average growth rate (Brzoza-Brzezina, 2007). However, this lack of convergence is considered to be a failure of the neoclassical growth model. There is gigantic distinction in per capita across economies. The poorest countries have per-capita incomes that are less than 5\% of per capita incomes in the richest countries (Jones, 1998). Why such thing happens? and explaining it are one of the fundamental

\footnotetext{
${ }^{1}$ See Kalyoncu (2008) for more detail.
} 
challenges of economics. Setting the aggregate production function as we have set may offer some insight into these differences. Besides how physical and human capital fit into this discussion is another point. We focus on the productivity which is closely related with the technology and ideas.

At an accounting level, differences in physical and human capital ratio per capita and to differences in productivity or physical to human capital ratio and productivity could cause differences in per capita income. Physical to human capital ratio and productivity differences are related with institutions and good governance in the countries besides other. Investments in infrastructure and human capital are necessary for growth. Empirically it is suggested that developing countries could catch up with the developed world if only they accomplished increased levels of human development. However, human improvement is a necessary but not a sufficient condition for growth.

A satisfactory level of infrastructure is an essential condition for the efficiency of firms. If we picture an economy without telephones, electricity or a road network which represent the infrastructure, then countries will need to build up a threshold or minimum level of infrastructure which means a minimum network of roads to make a difference for economy-wide productivity growth. Therefore, creating fiscal space for long-term investment in infrastructure, physical capital and human development are necessary. Developments in human and physical capital and infrastructural superiority have in need of adequate and sustained levels of public spending. Infrastructure improvement has in need of large-scale investments, which take time to establish. Improvements in education and health with their physical components also need longer-term efforts and have need of the permanent development and financing of social services. Good infrastructure, physical capital education and health can offer important communal gains and this may validates the government's central role in making sure that the public invests in them satisfactorily. 
There is a close relationship between productivity growth and structural change and economic growth requires structural change. For developed countries, growth and development are much more about pushing the technology frontier and much less about changing the structure of production than developing countries. However, for developing countries, it is much less about pushing the technological boundary and much more about changing the organization of production.

The level and character of structural change in investment patterns and structural change elucidate the diverging growth trends among developing countries. Labor productivity growth can be attained through either technological progress or by moving resources from low- to higher-productivity sectors or both. Structural change is closely related with ideas when ideas related to management. The growth process in the developed countries also involved a remarkable change in the employment structure, involving a reallocation from the primary sectors into industry and, subsequently, into services. Labor reallocation from low- to high-productive sectors may be more important in some cases than others. Since human development is a necessary but not a sufficient condition for sustained economic growth, lifting other restraints on economic growth and structural change will be necessary to create opportunities for a bettereducated population. In order to realize these structural changes, institutions and good governance are needed to set rules and regulation besides monitoring. In infrastructure, superior financing schemes and struggling corruption in the toning of infrastructural works could assist to lessen costs. It is now widely documented that institutions and governance structures are the issue for economic growth to explain widening global income disparity. However, the quality of institution and governance appear to be essentially countryand context-specific

Being good governance also means that both macroeconomic stability and policy flexibility are well managed since they are very important for growth. Macroeconomic permanence robustly 
manipulates the long-term growth routine of the economy. However, it should be considered beyond the just preserving price stability and sustainable fiscal balances such as about avoiding large swings in economic activity and employment and further, about maintaining sustainable external accounts and avoiding exchange-rate overvaluation. There is also an issue related with good governence which are linked to the production and diversion. If the resources have to choose between production and diversion, there may be more than one equilibrium such as an unfortunate equilibrium where production pays little because diversion is so widespread, and diversion has a high payoff because enforcement is useless when diversion is widespread. As a result, the self-possession of interruption is a vital element of a favorable social infrastructure. Therefore, government inserts the photograph in two ways. Firstly, the self-possession of interruption emerges to be most well-organized if it is carried out communally. Therefore, the government turns out to be the natural mechanism of anti-diversion hard works. Secondly, the authority to create and impose rules makes the government itself a very well-organized tool of diversion.

\section{Data and estimation}

The data on 1970, 1980, 1990 and 2000 is included for 69 countries. We list the countries included in the study at the appendix. Electric power consumption (kWh) (EL) stands for physical capital proxy. GDP per capita and electric power consumption (kWh) are taken from World Bank's World Development Indicators. Education (E) data comes from the Barro- Lee data set where it is represented by the average Years of School from Educational Attainment of the Aged 15. Dietary Energy Supply (DES) data is taken from FAO where "e" stands for worker effort level.

At the individual level, a worker's effort can be a function of the nutrient intake level where it is a quadratic function for the labor efficiency: where $\mathrm{e}^{\mathrm{i}}$ is efficiency units of labor for worker $\mathrm{i}$ and $x_{c}^{i}$ is the daily calorie intake at the individual level and it is 
assumed that all workers are identical in a particular country. It has been established that nutrition is the part of being healthy which is a part of human capital and it is a matter for economic outcomes. It is closely related with higher productivity, higher labor supply, increased technical skills as a result of higher education and specialized training and better access to liquid assets for investment in physical and intellectual capital (Thomas, 2001). Therefore, human capital is defined as education times the worker effort level $\left(\mathrm{H}=\mathrm{E}^{*} \mathrm{e}\right)$.

$$
\begin{aligned}
& e^{i}=\left(4.34 * 10^{(-4)}\right) *\left(x_{c}^{i}\right)-\left(4.16 * 10^{(-8)}\right)\left(x_{c}^{i}\right)^{2} ; \mathrm{e}=\mathrm{e}\left(\mathrm{x}_{\mathrm{c}}\right), \quad 3 \\
& \mathrm{e}^{\prime}>0 \text { and } \mathrm{e}^{\prime},<0
\end{aligned}
$$

where $e_{i}$ is efficiency units of labor for worker $i$ and $\chi_{c}^{i}$ is the day by day calorie intake at the individual level. It is assumed that all workers are one and the same in a country, so e shows countries' efficiency units of labor from an average worker and $\chi_{c}^{i}$ denotes per capita dietary energy supply (DES) where " $\mathrm{e}=\mathrm{e}\left(\mathrm{x}_{\mathrm{c}}\right), \quad \mathrm{e}^{\prime}>0$ and e" $<0 "$

\section{Table 1: Correlation}

\begin{tabular}{|l|c|c|c|c|c|c|c|}
\hline Whole & $\begin{array}{l}\text { Average } \\
\text { growth } \\
\text { rate }\end{array}$ & $\log \left(\mathrm{y}_{\mathrm{t}-\mathrm{T}}\right)$ & $\begin{array}{l}\mathrm{Ln}(\mathrm{EL} / \\
\mathrm{E})\end{array}$ & $\begin{array}{l}\text { TS } \\
\text { fact } \\
\text { ors }\end{array}$ & $\begin{array}{l}\text { ID } \\
\text { forHigh }\end{array}$ & $\begin{array}{l}\text { ID } \\
\text { for } \\
\text { Mid }\end{array}$ & $\begin{array}{l}\text { ID } \\
\text { for } \\
\text { Low }\end{array}$ \\
\hline $\begin{array}{l}\text { Average } \\
\text { growth rate }\end{array}$ & 1 & & & & & & \\
\hline $\log \left(\mathrm{y}_{\mathrm{t}-\mathrm{T}}\right)$ & 0.0538 & 1 & & & & & \\
\hline Ln(EL/E*e) & 0.2459 & 0.4173 & 1 & & & & \\
\hline $\begin{array}{l}\text { Time specific } \\
\text { factors }\end{array}$ & -0.1311 & 0.0977 & 0.1367 & 1 & & & \\
\hline ID for High & 0.1884 & 0.8238 & 0.386 & 0 & 1 & & \\
\hline ID for Mid & 0.0718 & -0.2429 & -0.1489 & 0 & -0.6363 & 1 & \\
\hline ID for Low & -0.2997 & -0.6371 & -0.2561 & 0 & -0.3606 & - & 1 \\
\hline
\end{tabular}

Note: ID = Income Dummies; TS factors: Economy-invariant time specific factor 
High

\begin{tabular}{|c|c|c|c|c|}
\hline Average growth rate & 1 & & & \\
\hline $\log \left(\mathrm{y}_{\mathrm{t}-\mathrm{T}}\right)$ & -0.561 & 1 & & \\
\hline $\operatorname{Ln}\left(\mathrm{EL} / \mathrm{E}^{*} \mathrm{e}\right)$ & -0.1023 & 0.2366 & 1 & \\
\hline Economy-invariant time specific factors & -0.1978 & 0.3816 & 0.1143 & 1 \\
\hline
\end{tabular}

Mid

\begin{tabular}{|l|c|c|c|c|}
\hline Average growth rate & 1 & & & \\
\hline $\log \left(\mathrm{y}_{\mathrm{t}-\mathrm{T}}\right)$ & -0.4516 & 1 & & \\
\hline $\mathrm{Ln}\left(\mathrm{EL} / \mathrm{E}^{*} \mathrm{e}\right)$ & 0.1081 & -0.0366 & 1 & \\
\hline Economy-invariant time specific factors & -0.1832 & 0.2005 & 0.1841 & 1 \\
\hline
\end{tabular}

\section{Low}

\begin{tabular}{|l|c|c|c|c|}
\hline Average growth rate & 1 & & & \\
\hline $\log \left(\mathrm{y}_{\mathrm{t}-\mathrm{T}}\right)$ & -0.4911 & 1 & & \\
\hline $\mathrm{Ln}\left(\mathrm{EL} / \mathrm{E}^{*} \mathrm{e}\right)$ & 0.438 & -0.2853 & 1 & \\
\hline Economy-invariant time specific factors & -0.0004 & 0.0754 & 0.1264 & 1 \\
\hline
\end{tabular}

In order to test for convergence, it is assumed that the countries in the sample are at their steady states. Therefore, studying the correlation between initial levels of income and subsequent growth rates helps us to confirm whether countries are at their steady states in table 1. It is because of the Solow type of models relying on diminishing marginal returns to capital where countries with low levels of capital stock will have higher marginal product of capital. Hence, at the similar saving rates, countries with low level of capital stock grow faster than those with already higher levels of per capita capital stock. Accordingly, finding of a negative correlation or no negative correlation between initial levels of income and subsequent growth rates is the popular criterion for judging whether or not convergence holds: finding negative correlation has the scope of being interpreted as evidence of convergence in terms of both income and growth rate and finding no negative correlation has the scope of being interpreted as an evidence of divergence in terms of both income and growth rate. There is a positive correlation between the initial level of income and the subsequent 47 
growth for the whole sample while for the sub sample; there is negative correlation between the initial income and the subsequent income growth.

For the whole sample, income dummies correlation with the percapita income growth rate demands our attention. Since for high and mid income level dummies we have positive correlation and negative correlation for low income level dummy, we can consider that there is a great structural differences among the income level. We also check the correlation between $\mathrm{Ln}\left(\mathrm{EL} / \mathrm{E}^{*} \mathrm{e}\right)$ and income dummies and we observe that for the high-income dummies it is positive and it is negative for the whole and the rest subsamples. For the sub samples $\mathrm{Ln}\left(\mathrm{EL} / \mathrm{E}^{*} \mathrm{e}\right)$ and $\log \left(\mathrm{y}_{\mathrm{t}-\mathrm{T}}\right)$ correlation is positive only for high but negative for the mid and low. For the whole and high sample growth rate and $\mathrm{Ln}\left(\mathrm{EL} / \mathrm{E}^{*} \mathrm{e}\right)$ correlation is negative but positive for mid and low.

The significant dummies may mean that superiority of the countries depends on not because of their physical and human capital sources or their ratio but the ambiance they create (Bulutay, 1995). He points out that agents (firms) of superiority in the production process are not created by their human and physical sources but the superiority is created by the ambiances with their sources. Therefore, firms and their property can be more valuable than what really they are because of created ambiance by firms.

Countries absolutely and significantly diverge even after economyinvariant time specific factors are included where the constant term of an economy-invariant time specific factors is $\left(g\left(t-e^{-\beta t_{t}}\right)\right)$. We also add the constant term of an economy-specific terms ( $\left.\left(1-e^{-\beta t}\right) \operatorname{Ln}\left(A_{0}\right)\right)$ and they cause the conditional convergence. The regressions are shown in Table $2 \mathrm{a}$ where their results are presented by Table $2 b$. 
Erdil,E.;Kalyoncu,K. Discussion on Idea and Technology in Solow's Model

Table 2a: Regression Equations for Absolute and Conditional Convergence

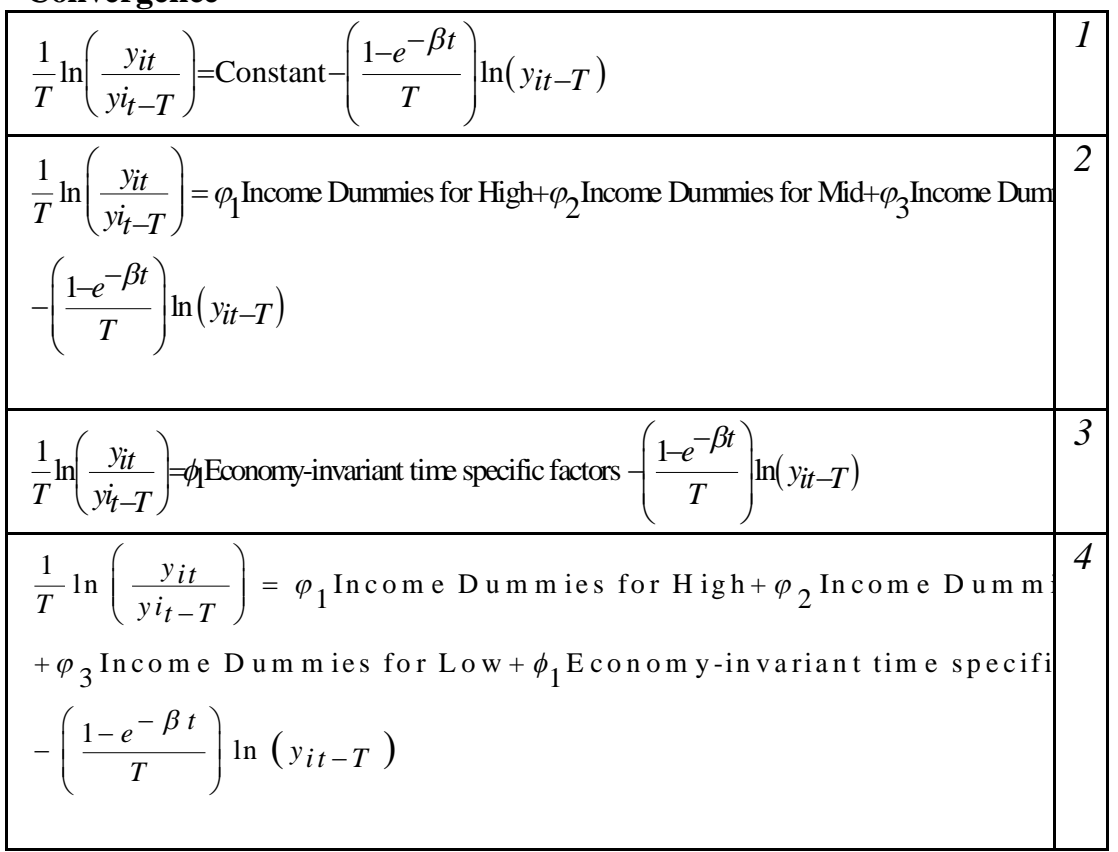

The individualsand joint tests of significance for dummies conclude that they are significant. Therefore, the magnitudes are not very high but they have great influences on the growth.

Investigating how the effects of (EL/E*e) only itself or with and besides other regional-specific conditions are also considered on the convergence. Therefore, the regressions are shown in Table $3 \mathrm{a}$ and the results are in Table $3 \mathrm{~b}$. Without any spesific affects, adding $\left(\mathrm{EL} / \mathrm{E}^{*} \mathrm{e}\right)$ causes convergence insignificantly. However, when we have specific affects we observe significant convergence. 
Table 2b: The Results of Absolute and Conditional Convergence with Dummies

\begin{tabular}{|c|c|c|c|c|}
\hline \multicolumn{5}{|c|}{ Dependent variable: GDP per-capita growth rate } \\
\hline & 1 & 2 & 3 & 4 \\
\hline \multirow{2}{*}{$\log \left(y_{t-T}\right)$} & 0.001 & 0.001 & -0.013 & -0.011 \\
\hline & $(1.98)^{*}$ & $(2.78)^{* *}$ & $(12.80)^{* *}$ & $(44.01)^{* *}$ \\
\hline \multirow{2}{*}{$\begin{array}{l}\text { Income Dummies } \\
\text { for High }\end{array}$} & & & 0.141 & 0.136 \\
\hline & & & $(14.99)^{* *}$ & $(65.61)^{* *}$ \\
\hline \multirow{2}{*}{$\begin{array}{l}\text { Income Dummies } \\
\text { for Mid }\end{array}$} & & & 0.113 & 0.112 \\
\hline & & & $(15.53)^{* *}$ & $(51.03) * *$ \\
\hline \multirow{2}{*}{$\begin{array}{l}\text { Income Dummies } \\
\text { for Low }\end{array}$} & & & 0.079 & 0.078 \\
\hline & & & $(12.54)^{* *}$ & $(32.40)^{* *}$ \\
\hline \multirow{2}{*}{$\begin{array}{l}\text { Economy- } \\
\text { invariant time } \\
\text { specific factors }\end{array}$} & & -0.00045 & & -0.0003 \\
\hline & & $(10.78) * *$ & & $(3070) * *$ \\
\hline \multirow[t]{2}{*}{ Constant } & 0.011 & 0.015 & & \\
\hline & $(2.28)^{*}$ & $(3.08)^{* *}$ & & \\
\hline Observations & 207 & 207 & 207 & 207 \\
\hline Wald & $\begin{array}{c}\text { Wald } \\
\text { chi2(1) } \\
=3.93\end{array}$ & $\begin{array}{c}\text { Wald } \\
\text { chi2(2) } \\
=116.25\end{array}$ & $\begin{array}{l}\text { Wald } \\
\text { chi2(4) } \\
=2549\end{array}$ & $\begin{array}{c}\text { Wald } \\
\text { chi2(5) } \\
=337767\end{array}$ \\
\hline
\end{tabular}

Absolute value of $\mathrm{z}$ statistics and its significance level are in parentheses and significant level shown with * at 5\%; ** significance level at $1 \%$ in all tables. 
Table 3a: Regression Equations for Conditional Convergence with (EL/E)

\begin{tabular}{|l|l|}
\hline$\frac{1}{T} \ln \left(\frac{y_{i t}}{y i_{t-T}}\right)=$ Constant $+\alpha\left(\frac{1-e^{-\beta t}}{T}\right) \operatorname{Ln}\left(\frac{E L}{E}\right)-\left(\frac{1-e^{-\beta t}}{T}\right) \ln \left(y_{i t-T}\right)$ & 1 \\
\hline$\frac{1}{T} \ln \left(\frac{y_{i t}}{y i_{t-T}}\right)=\varphi_{1}$ Income Dummies for High $+\varphi_{2}$ Income Dummies for Mid & 2 \\
$+\varphi_{3}$ Income Dummies for Low $+\alpha\left(\frac{1-e^{-\beta t}}{T}\right) \operatorname{Ln}\left(\frac{E L}{E^{*} e}\right)-\left(\frac{1-e^{-\beta t}}{T}\right) \ln \left(y_{i t-T}\right)$ & \\
\hline$\frac{1}{T} \ln \left(\frac{y_{i t}}{y_{i t}-T}\right)=\phi$ Economy-invariant time specific factors $+\alpha\left(\frac{1-e^{-\beta t}}{T}\right) \operatorname{Ln}\left(\frac{E L}{E}\right)-\left(\frac{1-e^{-\beta t}}{T}\right) \ln \left(y_{i t-T}\right)$ & 3 \\
\hline$\frac{1}{T} \ln \left(\frac{y_{i t}}{y i_{t}-T}\right)=\varphi_{1}$ Income Dummies for High $+\varphi_{2}$ Income Dummies for Mid & 4 \\
$+\varphi_{3}$ Income Dummies for Low $+\phi_{1}$ Economy-invariant time specific factors & \\
$+\alpha\left(\frac{1-e^{-\beta t}}{T}\right) \operatorname{Ln}\left(\frac{E L}{E}\right)-\left(\frac{1-e^{-\beta t}}{T}\right) \ln \left(y_{i t-T}\right)$ & \\
\hline
\end{tabular}

The individuals and joint tests of significance for dummies conclude that they are significant.

We also check how the constant term of an economy-specific term ( $\left.\left(1-e^{-\beta t}\right) \operatorname{Ln}\left(A_{0}\right)\right)$ works for each sub-samples. The constant term of an economy-invariant time specific factors $\left(g\left(t-e^{-\beta t_{0}}\right)\right.$ ) in these individual regressions will affect on the conditional convergence rate. It means that how the convergence rate will be influenced if there are income level differences or economy-invariant time specific factors or both. 
Table3b: The Results on Convergence with Dummies and (EL/E)

\begin{tabular}{|l|c|c|c|c|}
\hline Dependent variable: GDP per-capita growth rate \\
\hline & 1 & 2 & 3 & 4 \\
\hline $\log \left(\mathrm{y}_{\mathrm{t}-\mathrm{T}}\right)$ & -0.001 & -0.001 & -.0128 & -.013 \\
\hline & -1.56 & -0.91 & $\begin{array}{c}(- \\
12.64)^{* *}\end{array}$ & $\begin{array}{c}(- \\
13.11)^{* *}\end{array}$ \\
\hline Inc. Dummies for High & & & .099 & 0.107 \\
\hline & & & $(9.85)^{* *}$ & $(10.14)^{* *}$ \\
\hline Inc.Dummies for Mid & & & .07 & 0.08 \\
\hline & & & $(8.79)^{*}$ & $(8.86)^{* *}$ \\
\hline Inc. Dummies for Low & & & .04 & 0.0475 \\
\hline & & & $(5.41)^{*}$ & $(5.69)^{* *}$ \\
\hline $\begin{array}{l}\text { Economy-invariant } \\
\text { time specific factors }\end{array}$ & & 0 & & -.00008 \\
\hline & & $(8.58)^{* *}$ & & -1.38 \\
\hline Constant & -0.01 & -0.013 & & \\
\hline & -1.75 & -1.66 & & \\
\hline Ln(EL/E) & 0.002 & 0.002 & 0.002 & 0.0017 \\
\hline & $(6.25)^{* *}$ & $(4.54)^{* *}$ & $(5.83)^{* *}$ & $(4.65)^{* *}$ \\
\hline $\begin{array}{l}207 \\
\text { Observations }\end{array}$ & $\begin{array}{c}207 \\
\text { Wald } \\
\text { chi2(2) } \\
\text { Wald }\end{array}$ & $\begin{array}{c}\text { Wald } \\
\text { chi2(3) } \\
=10.62\end{array}$ & $\begin{array}{c}207 \\
\text { Wald } \\
\text { chi2(5) } \\
=2174\end{array}$ & $\begin{array}{c}207 \\
\text { Wald } \\
\text { chi2(6) } \\
=2096\end{array}$ \\
\hline
\end{tabular}

Absolute value of $\mathrm{z}$ statistics and its significance level are in parentheses and significant level shown with * at 5\%; ** significance level at $1 \%$ in all tables.

Table 4: Absolute Convergence For sub-Samples

Dependent variable: GDP per-capita growth rate

\begin{tabular}{|l|c|c|c|}
\hline & High & Mid & Low \\
\hline $\log \left(\mathrm{y}_{\mathrm{t}-\mathrm{T}}\right)$ & $-0.012(10.70)^{* *}$ & $-0.014(6.17)^{* *}$ & $-0.022(4.33)^{* *}$ \\
\hline Constant & $0.134(12.65)^{* *}$ & $0.122(7.51)^{* *}$ & $0.139(4.39)^{* *}$ \\
\hline Observations & 66 & 96 & 45 \\
\hline Wald chi2(1) & 114.42 & 38.02 & 18.72 \\
\hline
\end{tabular}

Absolute value of $\mathrm{z}$ statistics and its significance level are in parentheses and significant level shown with * at 5\%; ** significance level at $1 \%$ in all tables. 
Even though we have not observed absolute convergence for 207 observations, we observe absolute convergence for the sub-samples and we conclude that the convergence-club case may be applied for this cross-countries data (table 4).

Table 5: Convergence with Economy-invariant time specific factors for sub-Samples

\begin{tabular}{|l|c|c|c|}
\hline \multicolumn{4}{|l|}{ Dependent variable: GDP per-capita growth rate } \\
\hline & High & Mid & Low \\
\hline $\log \left(\mathrm{y}_{\mathrm{t}-\mathrm{T}}\right)$ & -0.011 & -0.016 & -0.025 \\
\hline & $(43.60)^{* *}$ & $(8.04)^{* *}$ & $(5.50)^{* *}$ \\
\hline Economy-invariant time specific factors & -0.0003. & -.0004 & 0.001 \\
\hline & $(-30.65)^{* *}$ & $(-3.54)^{* *}$ & $(7.92)^{* *}$ \\
\hline Constant & 0.136 & 0.15 & 0.137 \\
\hline & $(65.09)^{* *}$ & $(11.57)^{* *}$ & $(4.84)^{* *}$ \\
\hline Observations & 66 & 96 & 45 \\
\hline Number of index & 22 & 32 & 15 \\
\hline Wald chi2(2) & 13788.05 & 158.77 & 112.77 \\
\hline
\end{tabular}

Absolute value of $\mathrm{z}$ statistics and its significance level are in parentheses and significant level shown with * at 5\%; ** significance level at $1 \%$ in all tables.

Table 6: Convergence with Dummies and (EL/E) For sub-Samples

Dependent variable: GDP per-capita growth rate

\begin{tabular}{|l|c|c|c|}
\hline & High & Mid & Low \\
\hline $\log \left(\mathrm{y}_{\mathrm{t}-\mathrm{T}}\right)$ & -0.012 & -0.014 & -0.024 \\
\hline & $(10.72)^{* *}$ & $(6.67)^{* *}$ & $(5.12)^{* *}$ \\
\hline $\mathrm{Ln}\left(\mathrm{EL} / \mathrm{E}^{*} \mathrm{e}\right)$ & 0.001 & 0.003 & 0.004 \\
\hline & 1.53 & $(2.86)^{* *}$ & $(3.52)^{* *}$ \\
\hline Constant & 0.119 & 0.057 & 0.066 \\
\hline & $(8.94)^{* *}$ & $(2.41)^{*}$ & -1.84 \\
\hline Observations & 66 & 96 & 45 \\
\hline Wald chi2(2) & 115.06 & 45.44 & 36.96 \\
\hline
\end{tabular}

Absolute value of $\mathrm{z}$ statistics and its significance level are in parentheses and significant level shown with * at 5\%; and ** at $1 \%$ in all tables. 
The constant term of an economy-invariant time specific factors $\left(g\left(t-e^{-\beta t_{0}}\right)\right)$ in these individual income level regressions causes a higher convergence rate besides having very specific time coefficients for technological proxy. However, economy-invariant time specific factors and the constant terms for each sub-sample are not so different than each other in the table 5 .

The coefficients of $\left(\mathrm{EL} / \mathrm{E}^{*} \mathrm{e}\right)$ is insignificant for the rich sample while it is significant for the others. The constant terms are so different in the table 6 that may be consistent with steady state value of (EL/E*e) and growth rate depends on the technology at the steady state in Solow model for high-income countries.

Table 7: Convergence with Economy-invariant time specific factors and (EL/E) For sub-Samples

Dependent variable: GDP per-capita growth rate

\begin{tabular}{|l|c|c|c|}
\hline & High & Mid & Low \\
\hline $\log \left(\mathrm{y}_{\mathrm{t}-\mathrm{T}}\right)$ & -0.014 & -0.015 & -0.024 \\
\hline & $(-118.09)^{* *}$ & $(-7.17)^{* *}$ & $(-5.48)^{* *}$ \\
\hline Economy-invariant time specific factors & -.0003 & -0.001 & 0.001 \\
\hline & $(-46.62)^{* *}$ & $(-4.91)^{* *}$ & $(-5.98)^{* *}$ \\
\hline $\mathrm{Ln}\left(\mathrm{EL} / \mathrm{E}^{*} \mathrm{e}\right)$ & 0.001 & 0.004 & 0.003 \\
\hline & $(17.89)^{* *}$ & $(4.27)^{* *}$ & $(3.45)^{* *}$ \\
\hline Constant & 0.129 & 0.04 & 0.066 \\
\hline & $(48.31)^{* *}$ & -1.4 & -1.89 \\
\hline Observations & 66 & 96 & 45 \\
\hline Wald chi2(3) & $1.33 \mathrm{e}+09$ & 193.04 & 113.76 \\
\hline
\end{tabular}

Absolute value of $\mathrm{z}$ statistics and its significance level are in parentheses and significant level shown with * at 5\%; and ** at $1 \%$ in all tables.

The coefficients of (EL/E*e) are significant and highly significant than without time specific variable in table 7 . The constant terms are different which may lead us that as technology do not spread more easily despite of globalization and institutions across the world. 
Therefore, income levels will not also eventually converge to one another but the club convergence occurs.

These findings also enable a light on the issue of policy activism. The faster rate of convergence may appear to emphasize the policyirrelevance philosophy accredited to the Solow model. In reality, on the contrary, the vice versa is the case. Typically, only the saving and population growth rates were usually considered to be the variables for policies to be implemented. However, those findings emphasize the role of the $\mathrm{A}(0)$ term as a determinant of the steady state level of income. For that reason, without a doubt, even with the exact same rates of saving and population growth, a nation can also straightly develop its long-run economic situation by improving in the components of $\mathrm{A}(0)$ besides any simultaneous improvements in $\mathrm{A}(0)$, saving and population. These simulatenous growth can lead to a further (indirect) increase in the steady state level of income. Therefore, richer capacities for policies in raising the long-run incomes and in speeding up the pace of reaching them are the one of the key findings of the study. The current study helps us to form a correlation with the discussion in the recent work on growth empirics since we have lower alpha values for high sub-samples and the higher value for the low subsample. We check the alpha value (showing the different production function) by using the mean poulation growth rate of the sub-samples and it is $0.6,2$ and 2.5 for high, mid and low samples respectively.

Theoreticaly, it is not easy to conclude that $\left[\frac{K}{H}\right]_{\text {rich }} \stackrel{>}{\equiv}\left[\frac{K}{H}\right]_{\text {poor }}$. Therefore, we may focus on how $(\mathrm{K} / \mathrm{H})$ matches appropriately in the production function within a country. If $\left[\frac{K}{H}\right]_{p o o r}$ is more efficiently and effectively organized or matched in some period in time horizons with a given technology, then it is expected that the unfortunate will grow faster than the affluent. As a result, how long this will last is 
another issue to consider. It is surely expected that $\left[\frac{K}{H}\right]_{\text {rich }}$ is better organized surely than the poor. However, the issue may come up that if the rich countries develop a new technology and make use of this innovations by the economy.

When it takes place, it will surely require a structural change in the economy from low productivity sector to high one such as reallocation of productive factors in economies like moving from the agricultural to manufacturing sector or to high technology intensive, migration or mobility of factors. Therefore, this structural change in the affluent may cause the unfortunate grow faster than the affluent in the short run. It is because the process of adjusting and implementing this new technology take time. However, after that adjustment and implementation period takes its place, the affluent grows faster than the unfortunate in the long-run. That is also called level effetcs.

What happens when the unfortunate willing to implement this new technology is also another important issue, since implementing this newly developed technology by the unfortunate is less costly and even takes less time to adjust? It is expected that the unfortunate should get over this leapfrogging in the shorter term than the affluent. Therefore, observing a leapfrogging or short term fluctuation should not be surprising for the economist and in the long run, the unfortunate should grow faster than the affluent.

There is a very huge gap for electric consumption among the subsamples while there is no such gap for human capital proxy. Thus, $\left(\mathrm{EL} / \mathrm{E}^{*} \mathrm{e}\right)$ ratio are not closer at table 8 . The high-income (EL/E*e) is 6.56 times higher than the low and 3.44 times greater than the midincome level and it is 1.91 times for mid to low. However, in terms of just (EL), the gaps are twice greater. 
Table 8: Mean comparison rate of the some variables.

\begin{tabular}{|c|c|c|c|c|}
\hline Variables & Observations & Mean & & $\begin{array}{c}\text { Ratio of the } \\
\text { variables } \\
\text { according to } \\
\text { income level }\end{array}$ \\
\hline $\mathrm{E}^{*} \mathrm{e}$ & 45 & 183187.6 & Mid to low & 1.13 \\
\hline $\mathrm{E}^{*} \mathrm{e}$ & 96 & 206921.1 & High to Mid & 1.32 \\
\hline $\mathrm{E}^{*} \mathrm{e}$ & 66 & 273409.3 & High to Low & 1.49 \\
\hline $\mathrm{EL}$ & 45 & $2.35 \mathrm{E}+10$ & Mid to low & 2.27 \\
\hline $\mathrm{EL}$ & 96 & $5.33 \mathrm{E}+10$ & High to Mid & 5.67 \\
\hline EL & 66 & $3.02 \mathrm{E}+11$ & High to Low & 12.85 \\
\hline EL/E*e & 45 & 176463.3 & Mid to low & 1.91 \\
\hline EL/E*e & 96 & 336994.3 & High to Mid & 3.44 \\
\hline EL/E*e & 66 & 1157956 & High to Low & 6.56 \\
\hline $\ln \left(\mathrm{EL} / \mathrm{E}^{*} \mathrm{e}\right)$ & 45 & 21.04571 & Mid to low & 1.03 \\
\hline $\ln \left(\mathrm{EL} / \mathrm{E}^{*} \mathrm{e}\right)$ & 96 & 21.7047 & High to Mid & 1.07 \\
\hline $\ln \left(\mathrm{EL} / \mathrm{E}^{*} \mathrm{e}\right)$ & 66 & 23.18737 & High to Low & 1.10 \\
\hline
\end{tabular}

Since technology decides how the inputs into production function will be transformed, the cosntant economic term is especially important. A technological improvement requires the development in ideas in order to produce more and better output. However, while ideas are nonrivalrous, technology is not. An instruction and a person's ability that follow that instruction are rivalrous and the idea on that instruction is not rivalrous. However, even if the idea on the instruction is not rivalrous, since it is written on the paper or it is in mind of a person, which could make it partially rivalrous. Therefore, the idea and technology should be considered whether they are excludable.

Even if the ideas could spread very easily around the world, it may not spread its effect equally around the world. The knowledge broadly can be accesed by the people anywhere in the world even if internet becomes available world wide. However, in order to benefit up-to-date technology, organizational skills and distribution networks (spillover effects), foreign direct 
investment requires threshold levels, in income, human capital, technological know-how and enterprise development, being crossed before a significant positive impact can be identified (UN, 2006). There may be the reason for not observing world wide income convergence. That takes us back to considering the historical and institutional setting of each country: there are compulsory constraints on growth such as how the boundaries in mobilizing adequate domestic or foreign finance, the levels of human capital and technological capabilities, the governance structures and the poor functioning of institutions that regulate markets or provide public goods and social services function. The significance and importance of these boundaries tend to be different from country to country and it is supported by the income level dummies and sub-samples estimation results.

\section{Conclusion}

One of the key objects is how well physical to human capital ratio matches empirically in the growth model since whether the growth rate of output depends positively or negatively on the ratio of physical to human capital is an essential problem in the theory of growth. This paper provides evidence that this dependence tended to be positive in the sample of 69 countries from 1970, 1980, 1990 and 2000. Therefore, using this direct relationship between physical to human capital ratio and the income growth seems to be superior to existing studies. However, we have not reached convergence without the income dummies even if we include $(\mathrm{K} / \mathrm{H})$ in the regression for this data set. It is contradictory with suggestion that developing countries could catch up with the developed world if only they attained increased levels of human development. However, as our data points out in order to reach the convergence among the countries, not the physical to human capital ratio plays crucial role but the income level dummies. What these dummies indicate in our study?

We assume that they stand for establishment of institutions and governance structures besides the social structural and social cohesion. They could become a key variable for explaining widening global 
income disparity. We can hardly pin down which "quality" institutions and governance structures and etc should be pursued in order to support sustained growth processes since such quality appears to be essentially country- and context-specific. In order to set an adequate policy, we should aware of whether new economic prediction can be wide open in a significant conduct even when making more reserved and focused changes in the existing institutions and governance structures or so. Those are also related with the macro economic stability.

Macroeconomic determination robustly manipulates the long-term growth practice of the economy. Macroeconomic determination should be understood in broader terms such as controling and ruling more than just maintaining price steadiness and sustainable financial balances, keeping away from large swings in economic action and services and further, about keeping sustainable external accounts and staying away from exchange-rate overvaluation. The incidence of financial crises in developing countries reveal that macroeconomic steadiness is, in addition, about maintaining well-regulated domestic financial sectors, sound balance sheets within the banking system and sound external debt structures besides sound governing. That goes with what Bulutay (1995) emphasizes about the ambiance. As examples, think about the IBM and apple or think about Frank Sinara, Elvis Pressly, Micheal Jacson or so and the value they create are more valuable than what they realy have. Those people with their teams create such and air value greater than their individual values and team value. It just reminds me the contradictory setting of wine and international trade idea by Adam Smith. Besides Ricardo critizims, the choise of wine is contradictory to price idea since as time passess it becomes more valuable.

Diverging patterns of growth among developing countries are also visible in differences in terms of structural change. These fast-growing economies also show sustained increases in labour productivity and labour has moved from low- to high-productivity sectors, including modern service sectors. In the regions with low-growth performance, the employment shift to the service sector has been rather 
pronounced. Dynamic structural change involves strengthening economic linkages within the economy —in other words, integrating the domestic economy - and productivity improvements in all major sectors. The degree of integration of the domestic economy also influences how much countries are able to gain from international trade and investment. We try to point out how the external environment, macroeconomic policies and governance structures have shaped these differences in patterns of structural change. I would like to close the study with a short telling which supposed to show how the history and habits are important for the future development. It is said that some of the newest technological system depend on the 4 feet and 8.5 inch. For example:

- American space shuttle's gas tank size is 4 feet and 8.5 inch even if they try to make it bigger. Why is it? It is because they need a train to carry it to the launching loading ramp

- The size of the train and its railroad size that the train passes are 4 feet and 8.5 inch

Why 4 feet and 8.5 inch is important? The first train rails are designed from size of carriage. Then why is that size?Because the road made until this invent takes place are made such size if the bigger size is taken then the carriage are broken since it goes beyond the road size. Therefore, why the roads are made such size?Since the roads are from the Roman empire time for warriors and their carriages. Why the Romans built such size road but not bigger or small?The warriors' carriages are pulled by horses and these two horses' bottoms together side by side size is 4 feet and 8.5 inch.

Therefore, from the Romans to up to our era carriages are designed on that size. Briefly, nothing can be done since the fixed costs of the infrastructure are heavy.Therefore, some restriction has been created in the past and nothing can be done to change.

\section{References}

Barro, Robert and Sala-i-Martin, X. S (1995) "Economic Growth" McGraw-Hill, Inc.

Brzoza-Brzezina, M. (2007)

"http://akson.sgh.waw.pl/ mbrzez/Macro/Economic\%20growth.pdf" 
Bulutay, T. (1995) "Yeni Büyüme Kuramları ve Büyüme, Kalkınma Konusuda Diğer Bazı Yaklaşımlar" Devlet Planlama Teşkilatı, ISBN 975-19-0986-4

Doepke, M. (2007) "Human Capital and Growth: Lecture Notes of Economic Growth"

http://www.econ.ucla.edu/doepke/teaching/c32/sec3.pdf.

Erk, N., Çabuk, H. A. and Ateş, S (1998), Long-Run Growth and Physical Capital-Human Capital Concentration, ERC/METU METU International Conference in Economics II, Ankara, Turkey, Middle East Technical University

Islam, N. (1995) "Growth Empirics": A Panel Data Approach" Quarterly Journal Of Economics, 110, 4, 1127-70.

Jones, C. I. (1998) "Introduction to Economic Growth" W.W. Norton\&Company Inc.

Kalyoncu, K (2008) "An Assessment of the Effect of Health and Nutritional Quality on Worker Effort and Economic Growth Through Physical and Human Capital: Cross-Country and Turkish Evidence". $\mathrm{PhD}$ Thesis in MIDDLE EAST TECHNICAL UNIVERSITY http://etd.lib.metu.edu.tr/upload/12609606/index.pdf

Lucas, E. Robert, JR, (1990), "Why Doesn't Capital Flow from Rich to Poor Countries?" The American Economic Review, May, 92-96.

Ramcharan, R. (2004) "Higher or Basic Education? The Composition of Human Capital and Economic Development" IMF Staff Papers Vol. 51, No. 2, 2004 International Monetary Fund.

Rogers M. and Dowrick S. (1997) "Convergence and technology in the Solow-Swan growth model: an empirical analysis" working papers in economics and econometrics, The Australian National University.

United Nations (2006) "Diverging Growth and Development, World Economic and Social Survey 2006”, United Nations

Journal published by the EAAEDS: http://www.usc.es/economet/eaa.htm 
Table A: Country List

\begin{tabular}{|l|l|l|l|}
\hline High-income & Mid-income & Mid-income & Low-income \\
\hline Australia & Algeria & Peru & Bangladesh \\
\hline Austria & Argentina & Philippines & Benin \\
\hline Canada & Bolivia & South Africa & Cameroon \\
\hline Denmark & Botswana & Sri Lanka & Ghana \\
\hline Finland & Brazil & Syrian Arab Rep. & Haiti \\
\hline France & Bulgaria & Thailand & India \\
\hline Germany & Chile & Trinidad \&Tobago & Indonesia \\
\hline Greece & China & Tunisia & Kenya \\
\hline Iceland & Colombia & Turkey & Nicaragua \\
\hline Ireland & Costa Rica & Uruguay & Pakistan \\
\hline Italy & Dominican Rep. & & Senegal \\
\hline Japan & Ecuador & & Sudan \\
\hline Korea, Rep & Egypt Arap Rep. & & Togo \\
\hline Netherlands & Guatemala & & Zambia \\
\hline New Zealand & Honduras & & Zimbabwe \\
\hline Norway & Hungary & & \\
\hline Portugal & Iran Islamic Rep & & \\
\hline Spain & Jordan & & \\
\hline Sweden & Malaysia & & \\
\hline Switzerland & Mexico & & \\
\hline United Kingdom & Panama & & \\
\hline United States & Paraguay & & \\
\hline & & & \\
\hline
\end{tabular}

Note: for details of income classification, see World Bank 2002 classification. 